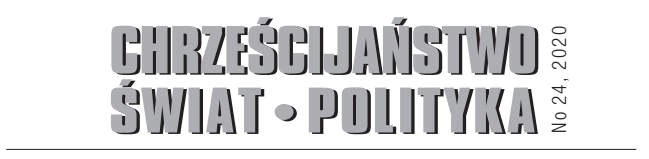

ZESZYTY SPOŁECZNEJ MYŚLI KOŚCIOŁA

\title{
Gérard-François Dumont
}

Sorbonne University, Francja

ORCID : 0000-0002-0256-2619

\section{Międzynarodowe ruchy migracyjne International migration movements}

Abstrakt: Kwestia migracji międzynarodowych jest coraz częściej poruszana w codziennych wiadomościach. Jednak mówią one tak naprawdę tylko o niewielkiej części tych ruchów, a mianowicie o exodusach związanych z wojnami międzynarodowymi lub domowymi, podsycanymi często - celowo lub nie - przez mocarstwa zewnętrzne, oraz o migracjach nielegalnych i wynikających często głównie ze złego zarządzania krajem. Natomiast ważne jest, aby pójść dalej i uchwycić kompletny i właściwy wymiar wszystkich migracji międzynarodowych, przyglądając się najbardziej rozpowszechnionym dyskursom mówiącym o świecie, który wszedł w powszechny cykl migracyjny i piętnującym niesymetryczny charakter pewnego rodzaju prawa do nomadyzmu. I w końcu, należy zastanowić się nad zmianami, którym podlegają migracje międzynarodowe w XXI w.

Słowa kluczowe: diaspora, demografia i badania ludności, emigracja, emigranci, ekonomia, geografia, geopolityka, migracja międzynarodowa, migracja, przestrzeń migracyjna.

Abstract: The issue of international migration has been increasingly present, especially since the early 2010 s, in the daily news. However, the media tends to focus on a small minority of these movements, those which arise from exoduses linked to international wars or to civil wars often fanned - voluntarily or involuntarily - by external powers, and those which take place in non-legal forms, the main cause of which is most often poor governance. Beyond that, it is important to take a complete and fair look at all international migration in daily life. However, this does not entail following sensationalist claims that depict a world entering a generalised migratory cycle. Finally, we should ask ourselves about the real changes undergone by international migration in the 21st century.

Keywords: diaspora, demography and population studies, economy, emigration, emigrants, geography, geopolitics, international migration, migration, migration space. 
Kwestia migracji międzynarodowych jest coraz częściej poruszana w codziennych wiadomościach. Jednak mówią one tak naprawdę tylko o niewielkiej części tych ruchów, a mianowicie o exodusach związanych z wojnami międzynarodowymi lub domowymi, podsycanymi często - celowo lub nie - przez mocarstwa zewnętrzne, oraz o migracjach nielegalnych i wynikających często głównie ze złego zarządzania krajem. Natomiast ważne jest, aby pójść dalej i uchwycić kompletny i właściwy wymiar wszystkich migracji międzynarodowych, przyglądając się najbardziej rozpowszechnionym dyskursom mówiącym o świecie, który wszedł w powszechny cykl migracyjny i piętnującym niesymetryczny charakter pewnego rodzaju prawa do nomadyzmu. I w końcu, należy zastanowić się nad zmianami, którym podlegają migracje międzynarodowe w XXI w.

\section{Masy ludzkie w ruchu?}

Pierwszy element, który należy odnotować, to fakt, że reprezentacja medialna zjawisk migracyjnych, skupiona na uchodźcach i migracjach nieuregulowanych prawnie, jest nadreprezentacją uwzględniającą tylko małą część międzynarodowych przepływów migracyjnych. W rzeczywistości większość migracji międzynarodowych przebiega w sposób uregulowany prawnie, z powodów zawodowych, rodzinnych lub edukacyjnych, tzn. migrują osoby posiadające dokumenty uprawniające, paszporty, wizy lub inne dokumenty, na mocy których ich migracja jest legalna.

Liczba imigrantów w rozumieniu definicji stosowanej przez wydział ds. ludności ONZ1 tzn. osób mieszkających, przez okres minimum 1 roku, w innym kraju niż kraj ich urodzenia, wynosi ona ok. 250 milionów, co należy odnieść do populacji światowej - 7,5 miliardów w 2017 r. [Sardon 2017]. W skali światowej, średnia skala migracji międzynarodowych w znaczny sposób odbiega od powszechnego jej postrzegania. W rzeczywistości, 96,7\% mieszkańców Ziemi mieszka w kraju urodzenia. Oznacza to, że znakomita większość ludzi woli żyć w kontekście kulturowym i geograficznym, który poznali w pierwszych latach życia.

Zauważmy ponadto, że liczba 250 milionów migrantów byłaby mniejsza, gdyby nie fakt, że zwiększyła się liczba krajów, a co za tym idzie długość granic międzypaństwowych. Na przykład Bośniak, który przenosi się do Chorwacji, jest teraz imigrantem, a nie było tak przed 1991 r., podobnie Czech przenoszący się na

1 Definicja geograficzna stosowana jest także przez Eurostat w Unii Europejskiej, natomiast nie przez Francję, której definicja wskutek dodania kryteriów prawnych jest mniej jasna. 
Słowację, mieszkaniec Sudanu Południowego emigrujący do Sudanu lub mieszkaniec Timoru Wschodniego, który zamieszkał w Indonezji. Powyższe dane liczbowe jasno pokazują, że mówienie o świecie, w którym migracje się upowszechniły, jest nie tylko przesadą, ale błędem. Rzeczywistość pokazuje coś przeciwnego: ogromna większość mieszkańców planety chce „żyć i pracować w swoim kraju”.

\section{Mnogość czynników warunkujących}

Są jednak ludzie, którzy emigrują z kraju swojego urodzenia. I to właśnie tę kwestię emigracji należy analizować zamiast, jak często to czynimy, obserwować imigrację. Oczywistym jest, że każdą imigrację, czyli osiedlenie się w innym kraju, poprzedza emigracja z jakiegoś kraju.

Przyczyny emigracji mogą być polityczne ${ }^{2}$, ekonomiczne i/lub demograficzne. W wielu przypadkach emigracja jest wyborem: chodzi o wykorzystanie możliwości zawodowych - mamy wówczas do czynienia ze zjawiskiem „migracji biznesowej”, spowodowanej bądź decyzją firmy skutkującą przemieszczeniem pracowników w sytuacji zmian na rynkach, bądź decyzją indywidualną przedsiębiorcy, otwierającą perspektywę nowego rynku pracy i większej satysfakcji zawodowej" [Wackermann 2005]. Inny rodzaj emigracji dobrowolnej ma miejsce, gdy chodzi o zamieszkanie w kraju współmałżonka. Jeszcze inny, gdy emigracja jest nie tyle wyborem samego emigranta, co skutkiem sytuacji rodzinnej i społecznej, która sprawia, że wybiera on poprawę warunków życia rodziny dzięki regularnym przesyłkom i przywożeniu towarów przy okazji poby tów imigranta w rodzinnym w kraju. Przykładem może być Senegal, gdzie zjawisko migracji jest elementem jego strukturalnego sposobu funkcjonowania. To, że przynajmniej jeden członek rodziny emigruje zagranicę stało się powszechną praktyką społeczną [Dumont, Kanté 2010; Kanté 2014].

W przeciwieństwie do emigracji dobrowolnej, inne rodzaje migracji są wymuszone lub odczuwane jako takie. Może to być ucieczka przed przemocą, a nawet śmiercią, która grozi danej osobie: emigracje z terytoriów byłej Jugosławii objętych wojną na początku lat 1990; wzmożona emigracja z Algierii do Francji podczas algierskiej wojny domowej w latach 1990 między władzą wojskową a islamistami; emigracja Syryjczyków lub Irakijczyków w latach 2010, nawet jeśli intensywność tej ostatniej związana była z jej specyficznym charakterem [Dumont 2015a]. Przykład Wybrzeża Kości Słoniowej: jest szczególnie wyrazisty, ponieważ kraj ten był

2 Począwszy od treści konstytucji, która wywiera wpływ na migracje [por. Dumont 2016]. 
dużym regionem imigracji w ciągu pierwszych czterdziestu lat niepodległości, gdy jego mieszkańcy właściwie nie znali zjawiska emigracji. Odwrócenie tendencji nastąpiło w latach 2000, gdy przez kraj przetoczyła się wojna domowa.

W innych przypadkach, emigracja polega na "głosowaniu nogami”, czyli na opuszczaniu kraju, którego niszczący wolność ustrój polityczny uciska ludność, uniemożliwiając prawdziwy rozwój. Dlatego setki tysięcy Chińczyków uciekło sampanami do Hongkongu, zwłaszcza w czasie głodu spowodowanego polityką „Wielkiego skoku do przodu” w latach 1958-1960. W okresie od utworzenia Niemieckiej Republiki Demokratycznej (NRD) w 1949 r. do wzniesienia muru berlińskiego w 1961 r., ponad 3,8 miliony mieszkańców wschodnich Niemiec opuściło swój kraj, który znalazł się pod jarzmem dyktatury komunistycznej [Münz, Ulrich 1998: 173-210]. W latach 1975-1980 rozgrywał się dramat boat people - ludności uciekającej przed morderczym reżimem komunistycznym w Wietnamie, a także mieszkańców Kambodży uciekających przed ludobójstwem. W 1989 r. ponownie wzrosła liczba obywateli wschodnich Niemiec wyjeżdżających wbrew woli władz: wyruszali swoimi samochodami (Trabant) nowym szlakiem migracyjnym przez Czechosłowację. Dziesiątki tysięcy „turystów” z NRD znalazły schronienie w ambasadach swojego kraju w Pradze i w Budapeszcie; inni pojawili się na granicy austro-węgierskiej, którą węgierski rząd zdecydował się otworzyć, przecinając druty kolczaste żelaznej kurtyny. Inny przykład to Kuba [Dumont 2015b]: poza okresami, najliczniejszymi, kiedy metodami policyjnymi uniemożliwiano emigrację, kraj ten stracił, od początku reżimu Castro, ponad 1 milion mieszkańców, czyli 12\% ludności, z których większość wyjechała do USA. Podobne zjawisko emigracji ilustrujące „głosowanie nogami” ma miejsce dzisiaj w wyniku dyktatury w Erytrei.

Czasami tłamszenie wolności w danym kraju dotyczy konkretnej części populacji, która zmuszona jest do emigracji: w 1956 r. w Egipcie polityka wydalenia objęła wszystkich mieszkańców niebędących Arabami wyznania muzułmańskiego ani Koptami, pomimo że znaczna ich część, jak Egipcjanie pochodzenia greckiego lub żydowskiego, mieszkali na terytorium Egiptu od ponad dwóch tysiącleci, a nawet dłużej. Inne przykłady to: Żydzi z Maghrebu pod koniec lat 1960; Europejczycy z Algierii w 1962 r.; Ugandyjczycy pochodzący z subkontynentu indyjskiego³ w 1972 r.; Palestyńczycy pracujący w Kuwejcie i wydaleni w 1991 r.,

3 Około 50000 zostało wydalonych, w większości do Wielkiej Brytanii, gdyż Indie nie były skłonne ich przyjąć w czasie gdy nie interesowały się swoimi diasporami [Dumont 2008a]. 
po tym jak zostali uznani przez rząd za popleczników Iraku, ponieważ polityczny lider Palestyńczyków, Yasser Arafat, opowiedział się po stronie Iraku Saddama Husseina w kontekście drugiej ${ }^{4}$ wojny w Zatoce Perskiej; hinduiści z Bangladeszu począwszy od lat 1990 wskutek umacniania się brutalnego islamizmu; zwiększona emigracja Koptów, zwłaszcza do Ameryki Północnej, w czasie, gdy Egiptowi przewodził członek bractwa muzułmańskiego od czerwca 2012 r. do lipca 2013 r.

Ogólnie rzecz ujmując, „głosowanie nogami” spowodowane jest głównie złym zarządzaniem gospodarką, nawet jeśli mieszkańcom nie grozi ograniczenie wolności. Widać to na przykładzie przepływów migracyjnych między Francją a Wielką Brytanią. W latach 70. ten drugi kraj był mało atrakcyjny ze względu na brak dynamiki gospodarczej. W związku z tym praktycznie żaden młody Francuz nie myśli o szukaniu możliwości zawodowych w Anglii, a młodzi Anglicy emigrują, najczęściej do krajów anglojęzycznych. Dwie dekady później, gospodarka Zjednoczonego Królestwa odzyskała dynamikę i na nowo stała się atrakcyjna, podczas gdy sytuacja we Francji pogorszyła się: w rezultacie, od lat 1990 Francja odnotowuje znaczną emigrację młodych ludzi do Wielkiej Brytanii. Można by mnożyć przykłady emigracji związanych ze złym zarządzaniem krajami, które niemniej jednak dysponują niekwestionowanym potencjałem rozwoju. Ponadto, emigracja zwana „ekonomiczną” z krajów Południa lub Północy jest, najczęściej, jednocześnie emigracją polityczną wynikającą z polityki państwa tolerującej nadużycia i wysoką korupcję.

W każdym razie, preferowanie kraju swojego urodzenia zauważane jest od początku historii ludzkości. Ponadto wielu imigrantów, jeśli mają taką możliwość, stara się wrócić do miejsca urodzenia. Zauważalne jest to w szczególności, gdy pokój i wolność lub nadzieja na powrót tych wartości zapanuje ponownie w krajach, z których te osoby wyemigrowały. Po 1 kwietnia 1939 r., po zakończeniu wojny domowej w Hiszpanii, większość Hiszpanów, którzy uciekli do Francji, powróciła do kraju. Po upadku dyktatury Batisty na Kubie w 1959 r., wielu Kubańczyków powróciło do kraju, licząc na przemiany demokratyczne. Bilans migracyjny Kuby był więc zdecydowanie dodatni w pierwszych miesiącach reżimu Castro. Następnie stał się na nowo ujemny, gdy okazało się, że ten reżim był gorszy niż poprzednia dyktatura. Po wprowadzeniu demokratycznych przemian w Portugalii w 1974 r., wielu obywateli tego kraju zdecydowało się na powrót na stałe lub spędzanie tam

4 Druga wojna w Zatoce Perskiej wobec pierwszej wojny iracko-irańskiej (1980-1988).

5 Pomyślmy o Ukrainie od lat 1990. 
regularnie wakacji. Po upadku żelaznej kurtyny i nastaniu demokracji w dawnych krajach komunistycznych w Europie środkowej, wschodniej i północnej, imigranci powrócili na stałe do swoich krajów, rezygnując z wygodnego życia w swoich nowych ojczyznach, np. USA w przypadku emigrantów z krajów bałtyckich.

Ponadto, przywiązanie do kraju urodzenia często przechodzi z pokolenia na pokolenie. Zdarza się więc, że potomkowie imigrantów chcą być pochowani w kraju urodzenia ich rodziców.

Świat nie jest więc areną powszechnych przepływów ludności, nawet jeśli dramaty geopolityczne, takie jak druga wojna światowa, ludobójstwo w Kambodży i w Rwandzie czy konflikty w Mezopotamii, spowodowały duże przepływy migracyjne i nie jesteśmy w stanie się uchronić przed takimi dramatami. Preferowanie swojego kraju urodzenia jest bardzo powszechne, co potwierdzają dane liczbowe. Inny często występujący pogląd opisuje niesymetryczność możliwości emigracji ze względu na kraj pochodzenia.

\section{Niesymetryczność możliwości migracji?}

Międzynarodowe zasady dotyczące emigracji są jasno określone: Powszechna Deklaracja Praw Człowieka, przyjęta 10 grudnia 1948 r. w Paryżu przez Zgromadzenie Ogólne ONZ, precyzuje dwa konteksty towarzyszące emigracji. Pierwszy, dotyczący emigracji wymuszonej, zdefiniowany w art. 14 mówi: „Każdy człowiek ma prawo ubiegać się o azyl i korzystać z niego w innym kraju w razie prześladowania". Bardziej ogólnie, deklaracja zapewnia prawo do emigracji w art. 13: „Każdy człowiek ma prawo opuścić jakikolwiek kraj, włączając w to swój własny, i powrócić do swego kraju”.

Wspomniany art. 13 jest zgodny z nauczaniem Kościoła, potwierdzonym, na przykład, w encyklice Jana XXIII, która przedstawia wolność migrowania w następujących słowach: „Każdy człowiek ma prawo [...], o ile ma ku temu ważny powód, wyjechać za granicę i się tam osiedlić". Tekst dodaje, że chodzi o „prawo przyrodzone człowiekowi” [Jan XXIII $1963: 25,106]$.

Tymczasem mimo międzynarodowego prawa do emigracji, regularnie się słyszy o niesymetrycznych możliwościach migracyjnych. Niektórzy uważają, że istnieje różnica między obywatelami pewnych krajów, mianowicie Północy, którzy mają duży wybór destynacji, gdyż są akceptowani w licznych krajach - 173 [Wihtol de Wenden 2017], a obywatelami krajów Południa, których możliwości migracyjne są mniejsze. 
Rzeczywistość wygląda inaczej, zarówno z punktu widzenia ilościowego jak i jakościowego. Wystarczy zapoznać się ze statystykami ONZ, aby zdać sobie sprawę z mnogości międzynarodowych przepływów migracyjnych. Statystyki te w żaden sposób nie wskazują na typologię krajów rozróżniającą te, których obywatelom byłoby łatwo migrować, i pozostałe ${ }^{6}$. Wystarczy stwierdzić do jakiego stopnia USA stały się tym co nazywam „państwem-światem” [Dumont 3013a] ze względu na fakt zamieszkiwania tam coraz bardziej zróżnicowanej populacji, pochodzącej z prawie wszystkich krajów z różnych kontynentów. Tę ewolucję tłumaczy fakt, że USA zniosły w 1965 r. kwoty geograficzne, które w znaczny sposób ograniczały możliwość imigracji do tego kraju obywatelom pewnych państw, w szczególności azjatyckich. Podobnie, imigranci obecni we Francji reprezentują ponad 150 różnych narodowości.

Jakościowo, rzekomy niesymetryczny charakter możliwości migracyjnych również należy odrzucić. Przypomnijmy, że wszystkie rządy świata mają za zadanie zapewnić bezpieczeństwo na swoim terytorium [Dumont 2017a] i uniemożliwić przedostanie się na to terytorium każdemu, kto wzbudza obawy, że spowoduje zaburzenie porządku publicznego.

Rolą rządów jest zapewnienie bezpieczeństwa osób i mienia, a także bezpieczeństwa sanitarnego. Oczywiście, pewne kraje idą w tym dalej, dążąc, za pomocą kontroli migracji, do innych celów, mniej zgodnych, a nawet przeciwnych dobru wspólnemu, takich jak cele polityczne, etniczne lub protekcjonistyczne. Jednak zasada ostrożności dla zapewnienia bezpieczeństwa jest powszechnie respektowana, zarówno na Północy jak i na Południu, co przekłada się na kontrole na granicach, czasem częstszymi w pewnych krajach Południa niż w krajach Północy. Wynika to z wymogów dotyczących otrzymania wizy lub dokumentów wjazdowych ${ }^{7}$. A wiza, która daje możliwość wjazdu do kraju, nie stanowi prawa wjazdu, ponieważ kraje zastrzegają sobie prawo wydalenia posiadacza wizy. To prawo kontroli migracyjnej, jeśli jest mądrze stosowane, nie jest w żaden sposób potępiane przez Kościół Katolicki. Uznaje on, że państwo, będąc gwarantem dobra wspólnego, może reglamentować wjazd na swoje terytorium, odstępując w drodze wyjątku od powszechnej zasady wolności emigracji i imigracji. Na przykład, tekst Pawła VI przyznaje państwom prawo regulowania kwestii wjazdu na ich terytorium, w drodze wyjątku od powszechnej zasady wolności emigracji i imigracji,

6 To rozróżnienie było jednak bardzo silne w czasach żelaznej kurtyny i muru berlińskiego [Dumont 2009]. Zmniejszyło się, mimo że wciąż istnieje wobec krajów rządzonych przez dyktatorów, takich jak Korea Płn.

7 Wymagając, na przykład, wcześniejszej rejestracji przez Internet. 
„prawa człowieka”, które władze państwowe powinny szanować. Wyjątek, który winien być uzasadniony „poważnymi i obiektywnie uzasadnionymi powodami, związanymi z dobrem wspólnym" [Paweł VI 1970: 58-72].

Obiektywna analiza międzynarodowych ruchów migracyjnych odrzuca więc zarówno stereotyp świata mas ludzkich będących w ruchu, jak i ten o niesymetrycznych możliwościach emigracji. Ponadto pozwala podkreślić dwie rzeczywiste zmiany w zakresie migracji międzynarodowych w XXI w., tj. nową logikę migracji oraz proces, który nazwałem „diasporyzacją”.

\section{Nowa logika migracji}

Od lat 90. widoczna jest istotna zmiana: czynnikami warunkującymi migracje międzynarodowe są teraz zarówno typowe elementy (polityczne, ekonomiczne, demograficzne lub wynikające z połączenia poszczególnych czynników) jak i „nowa logika migracyjna” [Dumont 2004 : 97-116 ${ }^{8}$; Dumont 2006] zrodzona z szeroko rozumianego "uświatowienia tubylczości”. Termin ten obejmuje trzy pojęcia wyjaśniające stymulację do migracji: „globalizacje”, „internacjonalizację” i „uświatowienie tubylczości” w ścisłym rozumieniu.

Globalizacja, jej wymiar normatywny, czyli wynikający z wyborów politycznych, sprzyja migracji międzynarodowej w ramach bloków regionalnych, które postanowiły ułatwiać swobodny przepływ osób, jak Unia Europejska, na mocy traktatów, lub Wspólnota Gospodarcza Państw Afryki Zachodniej (Cédéao) poprzez wprowadzenie wspólnego paszportu. W skali światowej, przystąpienie Chin do WTO świadczy o otwarciu na wymianę handlową, której w sposób nieunikniony towarzyszą migracje ludzkie. Inna decyzja związana z globalizacją: zniesienie kontroli wymiany walut przez bardzo wiele krajów daje imigrantowi swobodę przesyłania pieniędzy do kraju pochodzenia, przez co znika ewentualna przeszkoda w migracji.

Drugi wymiar, techniczny, „uświatowienie tubylczości” w szerokim rozumieniu tego słowa, internacjonalizacja, określa ogół technik i środków transportu osób, towarów, kapitałów i informacji zmniejszające dystans między terytoriami. Internacjonalizacja, która następuje w miarę postępu technicznego, pozwala uzyskać informacje, w łatwy sposób i w czasie rzeczywistym, o możliwościach migracyjnych, znacznie zmniejsza koszt transportu przepływów

8 Ten tekst ukazał się w zmienionej i uzupełnionej wersji w: Outre-Terre, revue française de géopolitique, nr 17, Éditions Eres, 2007. 
międzynarodowych i sprawia, że migracja nie wiąże się już z oddzieleniem od rodziny czy regionu pochodzenia dzięki licznym możliwościom komunikacji (telefon stacjonarny, komórkowy, e-mail, Skype i media społecznościowe).

Jeśli chodzi o uświatowienie tubylczości w ścisłym znaczeniu tego słowa, czyli wymiar biznesowy szeroko rozumianego uświatowienia tubylczości, jest to praktyczna konsekwencja globalizacji i internacjonalizacji dla podmiotów gospodarczych. Daje im to możliwość rozważania swojej obecnej lub przyszłej działalności gospodarczej w kontekście globalnym, a dotyczy to zarówno firm jednoosobowych jak i, oczywiście, przedsiębiorstw ponadnarodowych. Pierwsze mogą się skłonić ku migracji, aby wykorzystać możliwości, a drugie - aby przemieścić geograficznie swoich współpracowników zgodnie ze swoimi potrzebami.

Migracje międzynarodowe w XXI w. łączą więc klasyczne czynniki migracyjne $\mathrm{z}$ nową logiką migracji w wyniku procesów globalizacji i internacjonalizacji, co mnoży powody migracji i, przede wszystkim, umożliwia coraz bardziej złożone szlaki migracyjne. Ta złożoność zmienia profil migracyjny wielu krajów. Wcześniej dany kraj klasyfikowany był w jednej z trzech kategorii, w zależności od tego czy pełnił rolę kraju emigracji, tranzy towego czy imigracji. Obecnie wiele krajów pełni jednocześnie dwie lub trzy z tych funkcji.

Geografia mogłaby sugerować, jak to się często przyjmuje, że migracja jest ściśle uzależniona od odległości. Nie jest to błędne i XXI w. wciąż charakteryzuje się istnieniem obszarów migracyjnych między sąsiednimi krajami. Jednak od lat dziewięćdziesiątych zauważalne jest uświatowienie migracji, co przekłada się na wzrost mnogiej migracji międzynarodowej, pomnożonej możliwościami informacyjnymi i komunikacyjnymi, podczas gdy wcześniej migracja międzynarodowa wykazywała się podejściem radialnym. Od końca XX w., wraz z końcem żelaznej kurtyny, rewolucją $\mathrm{w}$ transporcie i nowym rozdaniem w światowej gospodarce, upowszechnia się logika siatkowa, którą ułatwia rozwój środków komunikacji oraz rozwój sieci tworzonych przez dawnych imigrantów.

\section{Od migracji osadniczych do migracji o charakterze diasporycznym}

W ostatnich dekadach XX w. termin diaspora upowszechnił się w wyniku „nowej logiki migracji” [Dumont 2007a; Dumont 2007b; Dumont 2008b; Dumont 2015c]. Rzeczywiście, migracje w XXI w. są zupełnie inne od tych, jakie ludzkość mogła poznać w ciągu tysiącleci. Na przestrzeni dziejów ludzkości, jeszcze przez znaczną część XX w., migrant opuszczający swój kraj, aby osiedlić się w innym, nie mógł 
utrzymywać regularnych kontaktów z krajem swojego pochodzenia, a często nawet sporadyczne kontakty nie były możliwe. Koszt i czas transportu sprawiały, że niewyobrażalne było dla niego planowanie co jakiś czas wizyt w kraju swojego pochodzenia. Brak lub słabość środków komunikacji sprawiały, że nie dysponował regularnymi i bieżącymi informacjami, a jeszcze mniej natychmiastowymi, na temat wydarzeń w kraju swojego pochodzenia. Nie mógł utrzymywać stałych kontaktów z członkami swojej rodziny lub przyjaciółmi pozostającymi w kraju pochodzenia.

Innymi słowy, ze względu na słabość komunikacji przez wieki, migracja wiązała się z całkowitym zerwaniem więzi z miejscem pochodzenia. Separacja powodowała nieuniknione odcięcia kulturowe, nawet jeśli zdarzały się wyjątki, na przykład imigranci francuscy, którzy, osiedlając się w skupiskach, przy wysokiej dzietności, zdołali zachować swój język w Kanadzie9 .

W szeroko otwartym świecie, internacjonalizacja umożliwia, zwłaszcza od lat 1980, łatwy transport i natychmiastową komunikację z krajem pochodzenia, co skutkuje głębokimi zmianami w procesie migracji międzynarodowych.

Rzeczywiście, współczesne migracje korzystają z technik komunikacji zapewniających imigrantom możliwość łatwego utrzymywania kontaktu z ojczyzną dzięki dochodzącym stamtąd informacjom, poprzez informacje przekazywane przez imigrantów lub poprzez zmniejszenie dystansu i kosztów transportu, co ułatwia wymiany lub podróże między krajem zamieszkania a krajem pochodzenia. W przeszłości świat znał głównie migracje osadnicze, osiedlanie się w kraju przyjmującym wiązało się najczęściej z zerwaniem kontaktów, więzi z krajem pochodzenia. Migracje w XXI w. mają charakter diasporyczny, osiedlenie się w kraju przyjmującym nie wiąże się $\mathrm{z}$ definitywnym zerwaniem więzi z krajem pochodzenia i możliwe jest utrzymanie z nim kontaktów. Kontakty te nie są obowiązkowe i migrant (podobnie jak jego potomkowie) może, jeśli tak zdecyduje, zapomnieć o kraju pochodzenia. Może jednak, jeśli chce, łatwo utrzymywać więzi z rodziną lub przyjaciółmi pozostałymi w kraju, regularnie go odwiedzać lub zbudować tam dom. Często stwierdza się także więź emocjonalną, gdy pojawia się pragnienie bycia pochowanym w kraju swojego pochodzenia, np. w przypadku w Francuzów pochodzenia afrykańskiego lub portugalskiego.

9 Język, który jednak zmieniał się w inny sposób niż ten, którym mówiono w kraju pochodzenia, o czym świadczą seriale telewizyjne z Quebecu, transmitowane przez TV5 Monde, w których aktorzy mówią francuskim z Kanady, a TV5 Monde zamieszcza napisy w języku francuskim $z$ Francji. 
Zdarza się też, że utrzymywanie więzi z krajem pochodzenia jest utrudnione ze względu na panujący tam autorytarny reżim, który nie wydaje wiz, ogranicza połączenia lotnicze, cenzuruje przesyłki pocztowe lub kontroluje wiadomości mailowe. Jednak nawet w tym przypadku więź może przetrwać, przynajmniej w rozumieniu duchowym, dzięki przynależności do społeczności przechowujących pamięć o ziemi ojczystej, i ta duchowa tożsamość może stać się rzeczywistą w chwili, gdy kraj pochodzenia się otworzy.

To co nazwałem procesem „diasporyzacji” ${ }^{10}$ jest zresztą umacniane przez kraje pochodzenia, które realizują politykę mającą na celu rozwijanie więzi z ich obywatelami mieszkającymi zagranicą [Dumont 2017b]. Niektóre kraje uznają nawet dzieci, wnuki lub prawnuki urodzone w kraju imigracji swoich rodziców, dziadków lub pradziadków za swoich obywateli, którym niekiedy wydają paszporty. To oddziaływanie krajów pochodzenia na diaspory potwierdziło się 16 kwietnia 2017 r., gdy tureccy imigranci w Europie ${ }^{11}$, mający podwójne obywatelstwo lub tylko obywatelstwo kraju pochodzenia, zagłosowali, w dużo wyższych proporcjach niż Turcy mieszkający w Turcji, na korzyść Konstytucji znacznie bardziej autorytarnej i łamiącej zasadę podziału władzy ustanowioną przez Monteskiusza. Taki wynik głosowania osób mieszkających w krajach demokratycznych trudno wytłumaczyć, jeśli nie weźmiemy pod uwagę działań agitacyjnych, ${ }^{12}$ prowadzonych przez turecki rząd wśród Europejczyków tureckiego pochodzenia.

10 „Diasporyzacja” oznacza, że imigranci lub ich potomkowie, niezależnie od powodów migracji, a nawet jeśli mają obywatelstwo kraju pochodzenia, zachowują rzeczywiste lub zmitologizowane więzi z krajami pochodzenia i kultywują szczególne relacje z imigrantami lub potomkami imigrantów o tym samym pochodzeniu geograficznym, etnicznym, językowym lub religijnym [por. Dumont 2007c].

11 Ale nie ci mieszkający w USA i w Kanadzie - mniej liczni i wywodzący się głównie z tradycji kemalistycznej, tj. mniej sprzyjający islamizacji władzy w Turcji.

12 O tej działalności agitacyjnej świadczy na przykład bezpośrednio fakt, że tureccy wyborcy mieszkający w Europie i głosujący na „nie”, prosili dziennikarzy o zmianę ich imion i nazwisk. Por. Le Monde, 15 kwietnia 2017 r. Ze swojej strony, w lutym 2017 r., austriacki polityk z partii Zieloni, Peter Pilz, podkreślił, że, zgodnie z informacjami, które zebrał, imigranci pochodzenia tureckiego mieszkający w Europie współpracują z tureckimi służbami wywiadowczymi MIT, dostarczając im informacji i denuncjując "podejrzanych" Turków (tzn. przeciwników rządu Erdogana) mieszkających zagranicą, co prowadzi do aresztowań w Turcji: „Posiadam dokumenty o tajnych wiadomościach z 35 krajów. W 35 krajach, od Belgii po Australię, w Austrii też, Erdogan prowadzi działalność szpiegowską przy udziale tureckich ambasad. Były przypadki Austriaków tureckiego pochodzenia, którzy chcieli odwiedzić bliskich w Turcji i zostali aresztowani jeszcze przed kontrolą paszportów w Istambule za rzekome znieważenie tureckiego prezydenta w austriackiej kawiarni” (Kronen Zeitung, 19 lutego 2017). 


\section{Wzrost liczby osób mających podwójne obywatelstwo}

$\mathrm{Z}$ czynników diasporyzacji wynika nowe zjawisko. W przeszłości rzadko się zdarzało, aby ktoś posiadał dwa paszporty. Obecnie przypadki posiadania podwójnego obywatelstwa są coraz liczniejsze, dzięki zmianie lub wprowadzeniu nowych przepisów prawa i w związku ze zmianą sposobu działania poszczególnych osób. $\mathrm{Z}$ jednej strony, kraje takie jak USA lub Francja od dawna wydają paszporty zgodnie z zasadą prawa ziemi lub czynią to od początku XXI w., jak Niemcy, gdzie wcześniej obowiązywało prawo krwi. Z drugiej strony, kraje takie jak Algieria wydają paszporty osobom, które uznają, na podstawie prawa krwi lub zawarcia związku małżeńskiego, za swoich obywateli, nawet jeśli nie urodziły się w danym kraju. Kraje takie jak Indie oficjalnie wniosły o uznanie podwójnego obywatelstwa przez wszystkie państwa świata [Dumont 2008a].

Ponadto, wiele osób dąży do uzyskania podwójnego obywatelstwa, licząc na to, że zapewni im to w przyszłości lepszą ochronę i da im więcej możliwości. Dlatego mieszkanki Surinamu przeprawiają się przez rzekę Moroni, aby urodzić w Gujanie, czyli na terytorium francuskim, podobnie jak mieszkanki Anjouan pokonują na pokładzie kutrów rybackich 35 kilometrów dzielące je od oddziału porodowego szpitala w Mamoudzou, na wyspie Mayotta, który odnotowuje najwyższą liczbę urodzeń na obszarze administracyjnym Francji. W USA, gdzie obywatelstwo jest przyznawane po urodzeniu, na mocy prawa ziemi, wiele Meksykanek stara się urodzić na terytorium USA, a kliniki w Kalifornii specjalizują się w przyjmowaniu Chinek pragnących urodzić dziecko w USA. Inny przykład, po referendum brytyjskim w czerwcu 2016 r. w sprawie Brexitu, Francuzi mieszkający w UK zaczęli występować o brytyjski paszport. Do tego trzeba dodać wszystkie osoby z podwójnym obywatelstwem pochodzące z małżeństw mieszanych.

Powyższe przykłady ilustrują złożoność prawną kwestii podwójnego obywatelstwa, przy czym przypadki te można dzielić na trzy rodzaje. W pierwszym przypadku podwójne obywatelstwo jest podwójnie uznane przez dwa (lub trzy) kraje, których ono dotyczy, ponieważ osoby otrzymujące drugie obywatelstwo nie są zmuszone do rezygnacji z pierwszego. W drugim, podwójne obywatelstwo jest uznane tylko przez jeden z krajów - ten, którego przepisy na nie zezwalają, podczas gdy drugi kraj go nie uznaje. I wreszcie trzeci rodzaj, gdzie podwójne obywatelstwo nie jest uznawane ani przez pierwszy kraj, który wydał paszport, ani przez drugi. Osoba otrzymująca drugi paszport oświadczyła, że rezygnuje z pierwszego, ale nie miało to miejsca, ponieważ pierwszy kraj zabrania rezygnowania z obywatelstwa. 
Świat w XXI w. stoi wobec konieczności prawdziwego zmierzenia się z rzeczywistością migracyjną, odrzucając tak często obecne stereotypy i nie zapominając o znacznej różnorodności systemów migracyjnych w zależności od kraju i czasu. Należy wziąć pod uwagę intensywność zmian jakościowych migracji międzynarodowych na skutek nowej logiki migracji oraz procesu „diasporyzacji”. Ten ostatni wynika głównie ze znacznego zmniejszenia dystansu między krajami świata, niekiedy prawie jego zniknięcia dzięki technologiom informacyjnym i komunikacyjnym. Ale intensyfikacja migracji może też wynikać z działań politycznych krajów pochodzenia, działań pożądanych, gdy mają na celu dobro wspólne, ale dużo mniej pożądanych, gdy chodzi o manipulację geopolityczną, wewnętrzną lub zewnętrzną, w stosunku do diaspor. W tym kontekście wzrasta złożoność kwestii integracji imigrantów, mimo że jest ona równie niezbędna, a nawet bezwzględnie konieczna, w celu zapewniania zgody społecznej między osobami zamieszkującymi to samo terytorium.

Aby przynieść właściwe odpowiedzi na to pytanie o integrację, aby pokonać napięcia społeczne, które mogą wyniknąć z obecności imigrantów na danym terytorium, aby migracje były czynnikami pokoju, a nie konfliktów [Dumont 2013b ; Dumont 2013c], możliwe jest odniesienie się do paragrafu 2241 Katechizmu Kościoła Katolickiego:

„Narody bardziej uprzywilejowane powinny przyjmować w miarę swoich możliwości cudzoziemców szukajacych bezpieczeństwa i zasobów życiowych, których nie moga znaleźć w kraju swojego pochodzenia. Władze państwowe będa czuwaty nad poszanowaniem prawa naturalnego, zgodnie z którym gość znajduje się pod ochrona tych, którzy go przyjmuja. (...) Władze polityczne moga, majac na względzie dobro wspólne, za które sq odpowiedzialne, podporzadkować korzystanie z prawa do imigracji różnym warunkom prawnym, w szczególności poszanowaniu obowiązków migrantów wobec kraju przyjmującego. Imigrant powinien respektować $z$ wdzięcznością dziedzictwo materialne i duchowe kraju przyjmującego, stosować się do jego praw i uczestniczyć w jego obciążeniach.” 


\section{Bibliografia}

Dumont G.-F. (2004), Les nouvelles logiques migratoires, dans: Y. Michaud (direction), Qu'est-ce que la Globalisation ?, Éditions Odile Jacob, Paris.

Dumont G.-F. (2006), Migrations internationales et mondialisation, dans : G. Wackermann (direction), La mondialisation, Ellipses, Paris.

Dumont G.-F. (2007a), Les nouvelles logiques migratoires au XXI esièle, "Outre-Terre, revue française de géopolitique", $\mathrm{n}^{\circ} 17$, Éditions Eres.

Dumont G.-F. (2007b), The new logic of migration in the Twenty-First Century, "Geopolitical Affairs", London, volume 1, number 2, summer.

Dumont G.-F. (2007c), Démographie politique. Les lois de la géopolitique des populations, Ellipses, Paris.

Dumont G.-F. (2008a), Un nouvel acteur géopolitique : la diaspora indienne, "Géostratégiques", n 19, April.

Dumont G.-F. (2008b), La nueva logica migratoria des s. XXI, "Debats", n 99, Valencia, Spain, Invierno-primavera.

Dumont G.-F. (2009), Le mur de Berlin : vie, mort et héritage géopolitique, Diploweb.com, "La revue géopolitique", 18 October.

Dumont G.-F. (2013a), Les États-Unis: un État-Monde, "Population \& Avenir", n 714, September-October.

Dumont G.-F. (2013b), La paix à l'âge des nouvelles logiques migratoires. The Global Quest for Tranquilitas Ordinis. Pacem in Terris, Fifty Years Later, Pontifical Academy of Social Sciences (PASS), Acta 18.

Dumont G.-F. (2013c), Gouvernance internationales et politiques migratoires, dans: E. de Moulins-Beaufort, P. Poirier (editor), Gouvernance mondiale et éthique au XXIe siècle, Collège des Bernardins, Lethielleux, Paris.

Dumont G.-F. (2015a), Syrie et Irak : une migration sans précédent historique?, Diploweb. com, "La revue géopolitique", 12 December.

Dumont G.-F. (2015b), Cuba: histoire d'un exode, "Population \& Avenir", n 725, November-December.

Dumont G.-F. (2015c), Les migrations internationales au XXI siècle: des facteurs récurrents ou nouveaux?, “Actuelles de l'IFRI”, September.

Dumont G.-F. (2016), Géopolitique des migrations: les effets répulsifs ou attractifs des Constitutions, Diploweb.com, "La revue géopolitique", 26 June.

Dumont G.-F. (2017a), Des migrations incontrôlées, "Questions internationales”, n 85-86, June.

Dumont G.-F. (2017b), Immigration : la question de l'intégration dans un contexte fondamentalement nouveau, "Les analyses de Population \& Avenir", April.

Dumont G.-F., Kanté S. (2010), L'émigration sénégalaise : autant Sud-Sud que Sud-Nord, dans : V. Moriniaux (direction), Les mobilités, Éditions Sedes, Paris.

Jan XXIII (1963), "Pacem in terris", on peace among all nations based on truth, justice, love and freedom, Vatican.

Kanté S. (2014), Géopolitique de l'émigration sénégalaise en France et aux Etats-Unis, L'Harmattan, Paris. 
Münz R., Ulrich R. (1998), Les migrations en Allemagne : 1945-1996, “Revue européenne des migrations internationales", vol. 14, $\mathrm{n}^{\circ} 2$.

Paweł VI (1970), Motu Proprio "Pastoralis migratorum cura" (1970), "La Documentation catholique", no. 1555.

Sardon J.-P. (2017), La population des continents et des pays, "Population \& Avenir", n 735, November-December.

Wackermann G. (2005) (editor), Dictionnaire de géographie, Ellipses, Paris.

Wihtol de Wenden C. (2017), La question migratoire au $21^{\circ}$ siècle, Presses de Sciences Po, Paris. 